\title{
ON PRESSURE DROP THROUGH BRANCHED DUCTS
}

\author{
Bahgat K. Morsy, Fahad Al-Mufadi and A.E. Abdelraheim \\ Mechanical Engineering Department, College of Engineering, Qassim University, KSA \\ bahgat52@yahoo.com
}

\begin{abstract}
An experimental loop was designed and constructed in order to simulate air duct systems usually adopted in industrial processes. In this work, the loop consisted of two main branches; each branch could be fixed at desired angle of inclination ranging from $15^{\circ}$ to $90^{\circ}$ from the axis of the main duct. The losses of energy due to pressure drop through the duct were measured at different points through the loop. Experiments were performed at different flow rates with various air exits at Reynolds number between $4.6 \times 10^{4}$ and $10.2 \times 10^{4}$.
\end{abstract}

The objectives of the present work are to predict the pressure losses through air in the variable volume control system as well as to determine the optimum angle of inclination to cause minimum pressure drop. It has been found that the percentage of the air exit opening and the degree of inclination of branched duct have significant influence on the energy losses due to the pressure drop.

Results from the present study showed that with an angle of $90^{\circ}$ and a full exit opening as well as with an angle of $15^{\circ}$ and $75 \%$ of the exit opening, the pressure drop reached its minimum value. This can be attributed to the existence of the secondary flow within the elbow. It was also observed that more narrowing of air exit resulted in increased generation of back pressure inside the duct at different sections. This significant observation makes it possible to rely upon the design of the present loop when the air variable volume control system is utilized in industry.

Keywords: Branded ducts, Flow rates, Reynolds number, Pressure losses, Darcy law.

\section{INTRODUCTION}

Duct systems, commonly used for air distribution, may be classified into four categorical types, namely, simple dividing or combining flow and parallel or reverse flow duct systems. The parallel and reverse flow systems are combination of the basic dividing and combining flow ducts interconnected by lateral branches.

In a dividing flow duct, the main fluid stream is decelerated due to the loss of fluid through the laterals. Therefore, pressure rises in the direction of flow if the effects of friction are small as can be demonstrated by applying a frictionless Bernoulli equation to the duct flow stream.

Frictional effects however would cause a decrease of pressure in the flow direction. Therefore, the possibility exists for obtaining a uniform pressure along the dividing flow duct by suitable adjustment of the flow parameters so that the pressure region due to flow branching balances the pressure losses due to friction. If the flow field is considered as one dimensional, the governing equations for the 
dividing flow are the continuity and momentum equations. Under suitable assumptions, the work energy equation can also be applied to the duct flow stream. The prediction of the performance of the system depends on the proper selection of the momentum exchange and discharge coefficient and the formulation of a valid physical model for the branching process. The prediction of the lateral flows for a duct with many branches is accomplished more readily by a continuous flow model as opposed to a discrete branch point model.

The main outcome of this study is to present an experimental technique that could be applicable to simulate the actual flow distribution in branched ducts used in air conditioning. The objectives, however, of the present work are to predict the pressure losses through air variable volume control system as well as to determine the optimum angle of inclination to cause minimum pressure drop.

Early experimental work concentrated on determining flow coefficients at single, isolated branch points.

The major contribution to the data for pressure changes and flow loss coefficients at discrete branch points was made by McNown [1] for circular pipes with right angled, sharpedged junctions between the lateral and the duct.

Other experimental data have been reported for these geometries by Ruus [2] and Kubo and Ueda [3, 4]. Flow coefficients for other lateral geometries, such as simple holes or short tubes, have been determined by koh and Brooks [5], Acrivos and et al. [6] and Dittrich [7]. Much of the data for flow coefficients had obtained for branched points which are infinitely spaced along the header and, therefore, the relevance of this data to situations where branch points were closely spaced is questionable.
McNown [1] has shown that the pressure regain characteristics at a branch point are strongly dependent on the spacing between laterals. The results of Kubo and Ueda [3] illustrated that the flow coefficients many be considered as independent of Reynolds number for a wide flow range. For discharge ports in a lock system which included the effect of axial momentum transport by the transverse flow stream, an analytical model was developed by Bajura [8] and applied to both dividing and combining flow ducts. The flow model proposed by this reference was more physically acceptable to be applied in actual conditions of branching systems.

Gas-flow dynamics in internal gas manifolds of a fuel-cell stack are analyzed to investigate overall pressure variation and flow distribution [11]. Different gas-flow patterns were considered in this analysis. Gas-flow through gas channels of each cell is modeled by means of Darcy's law where permeability should be determined on an experimental basis. Gas-flow in manifolds is modeled from the macroscopic mechanical energy balance with pressure-loss by wall friction and geometrical effects. A systematic algorithm to solve the proposed flow model is suggested to calculate pressure and flow distribution in fuel-cell stacks. Calculation is done for a 100cell molten carbonate fuel-cell stack with internal manifolds. The results show that the pressure-loss by wall friction is negligible compared with the pressure recovery in inlet manifolds or loss in outlet manifolds due to mass dividing or combining flow at manifoldcell junctions. A more significant effect on manifold pressure possibly arises from the geometrical manifold structure which depends on the manifold size and shape. The geometrical effect is approximated from pressure-loss coefficients of several types of fittings and valves. The overall pressure and 
flow distribution is significantly affected by the value of the geometrical pressure-loss coefficient. It was also found that the flow in manifolds was mostly turbulent in the 100cell stack thereby resulted in an uneven flow distribution when the stack manifold was incorrectly, designed.

The pressure variation and the flow distribution in the manifold of a fuel-cell stack were simulated by a computational fluid dynamics (CFD) approach [12]. Two dimensional stack model composed of 72 cells filled with porous media was constructed to evaluate pressure drop caused by channel flow resistance. In order to simplify this model, electrochemical reactions, heat and mass transport phenomena were ignored and air was treated as working fluid to investigate flow distribution in stacks. Design parameters such as the permeability of the porous media, the manifold width and the air feeding rate were changed to estimate uniformity of the flow distribution in the manifold. A momentum-balance theory and a pressuredrop model were presented to explain the physical mechanism of flow distribution. Modeling results indicate that both the channel resistance and the manifold width can enhance the uniformity of the flow distribution. In addition, a lower air feeding rate can also enhance the uniformity of flow distribution. However, excessive pressure drop is not beneficial for realistic applications of a fuel-cell stack and hence enhanced manifold width was a better solution for flow distribution.

The prediction of flow distribution in flow manifolds is important for the design of heat exchangers [13]. The pressure drop along the flow in the header is the most influential factor in flow distribution. Various continuous models available in literature have failed to satisfactorily predict the pressure distribution in the headers of the flow manifolds. In this article, a discrete model matching the real physical phenomena has been proposed, to predict the pressure distribution in headers. An experimental evaluation of relevant flow characteristic parameters has been carried out to support the discrete model calculations. The validity of the theoretical discrete model has been performed with experimental results, under specific conditions. Refined experimental probes, for pressure heads with ultrasonic measuring devices, have been used to obtain accurate results. The experimental results fully substantiate the soundness of the theoretical prediction. In addition, the advantage of the ability to accommodate local disturbances in the discrete model has been pointed out. The effect of some local disturbances may be substantial. As a result of the analysis presented in this article, improved designs of flow manifolds in heat exchangers can be realized, to assure operation safety under severe operating conditions.

A detailed review and analysis of the hydrodynamic characteristics of laminar developing and fully developed flows in noncircular ducts was presented [14]. New models were proposed, which simplify the prediction of the friction factor-Reynolds product $f \mathrm{Re}$ for developing and fully developed flows in most noncircular duct geometries found in heat exchanger applications. By means of scaling analysis it was shown that complete problem may be easily analyzed by combining the asymptotic results for the short and long ducts. Through the introduction of a new characteristic length scale, the square root of cross-sectional area, the effect of duct shape has been minimized. The new model has an accuracy of $\pm 10 \%$ or better for most common duct shapes when nominal aspect ratios are used, and $\pm 3 \%$ or 
better when effective aspect ratios are used. Both singly and doubly connected ducts are considered.

The use of high-efficiency filtration was a common strategy to control exposure to particulate matter in buildings [15]. However, filters were perceived to be associated with large energy penalties. This research explored the potential energy impacts of higher efficiency filters in residential forced-air cooling systems. A literature review of the likely impacts of filters on energy use, including changes in fan power draw, airconditioner compressor power draw, cooling capacity, and duct leakage suggests small energy consequences and potentially even energy savings. The magnitude of filter impacts was especially insignificant when compared to other common air-conditioner operation and maintenance issues.

\section{EXPERIMENTAL APPARATUS}

A schematic drawing of the experimental apparatus is shown in Fig. 1. Dimensions of the main duct and branch as well as the measuring locations are given in Fig. 2. The main duct and laterals were fabricated from commercial galvanized steel sheets of 0.75 $\mathrm{mm}$ thickness. The air flow through the system was induced by connecting the outlet of the blower (1) having a power of $3 \mathrm{~kW}$ to the inlet of the main duct (2) with rectangular cross - section. The second part of this duct (3) was designed in such a way that could facilitate the inclination of the outlet by angles $15^{\circ}, 30^{\circ}, 45^{\circ}, 60^{\circ}$, and $90^{\circ}$ to the axis of the main duct. This arrangement was selected to investigate the influence of the inclination on the energy losses due to pressure drop. The extension of the main duct is represented by the shown horizontal duct. The pressure at each measuring locations was measured by the multi - tube manometer while the velocity and the discharge flow rate were determined using Pitot - tube.

\section{ANALYSIS OF THE MEASUREMENT ACCURACY}

\subsection{ERROR SOURCES}

The main sources of error involved in the present work were due to the measurements of velocity which were utilized to determine the flow rate and Reynolds numbers the measurements of pressure drop. Since the main parameter in the present experiments, to be changed, was the angle of inclination of the air exit, the error was of order \pm 1 degree in the positioning of each run. The error to this case represents about $\pm 1.1 \%$.

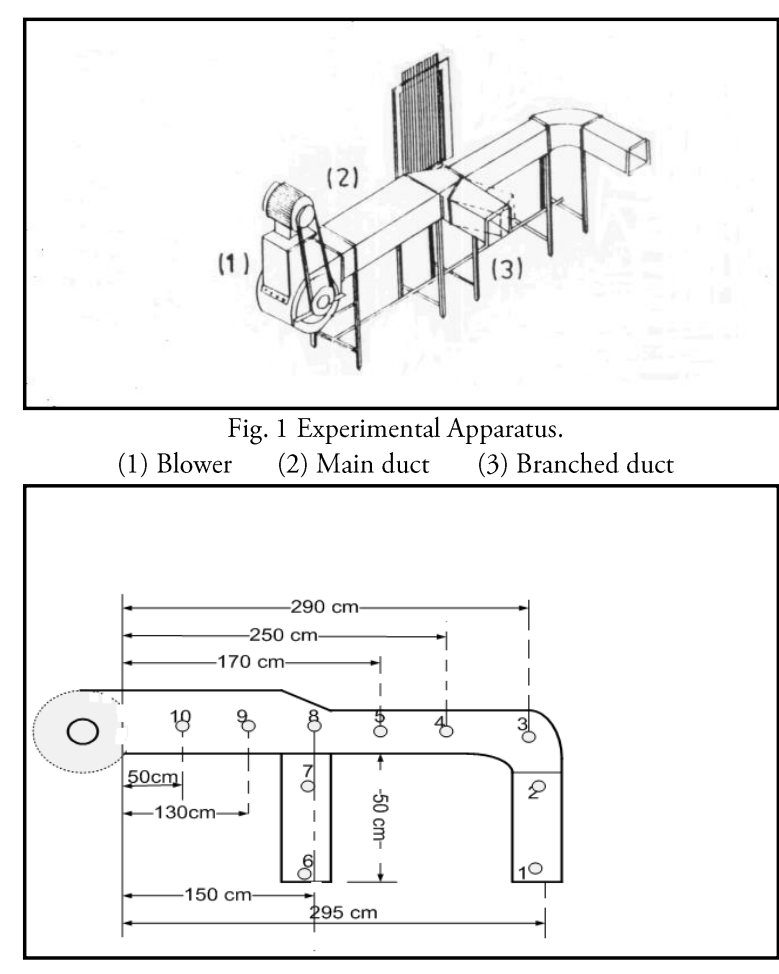

Fig. 2 locations of measuring points

\subsection{ERROR IN VELOCITY MEASUREMENTS}

In the present work, Pitot tube was used to measure the velocity in order to determine the air flow rate and the corresponding Reynolds number. When calibrating the Pitot tube the value of velocity measured by Pitot tube might differ slightly from the true velocity. Therefore; a coefficient of about 0.98 was 
introduced in order to compensate for this variation. The maximum error is equal $\pm 0.5 \%$ in the magnitude of the measured velocity in the duct.

\subsection{ERROR IN PRESSURE MEASUREMENTS}

Although there were significant turbulent fluctuations at the measured stations on the duct, no noticeable fluctuations were observed on the multi - tube differential manometer scale. This way is attributed to damping of such fluctuations through the rubber pipes. This error was difficult to be analyzed since such fluctuations were random. It was in general of order $\pm 2 \mathrm{~mm}$ on the manometer scale.

\section{RESULTS AND DISCUSSIONS}

Experiments were carried out at Reynolds number between $4.6 \times 10^{4}$ and $10.2 \times 10^{4}$ based on the inlet cross - section of the main duct. Experimental results for the pressure drop along the loop, in dimensionless presentation, are shown in (Figures 3 to 9). The description of these figures may be given as:

Figures 3 and 4 represent the pressure drop related to the kinetic energy along different points.

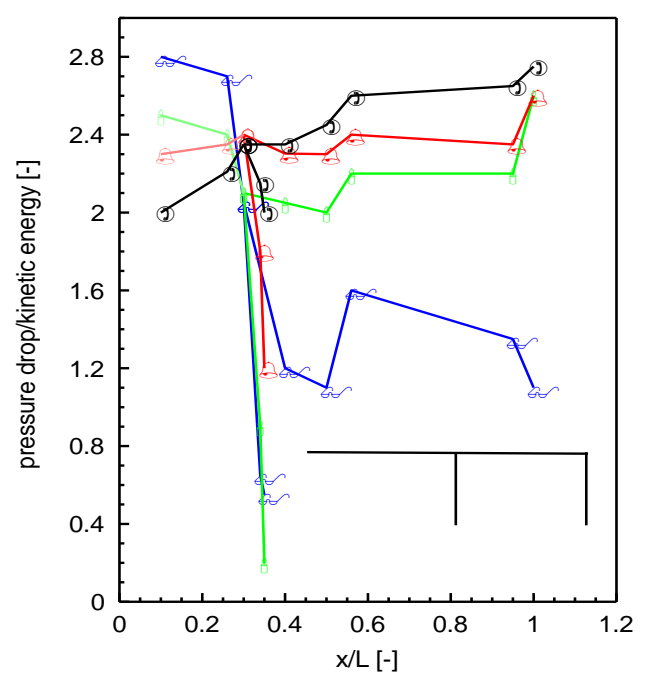

(a) branched angle $=90^{\circ}$

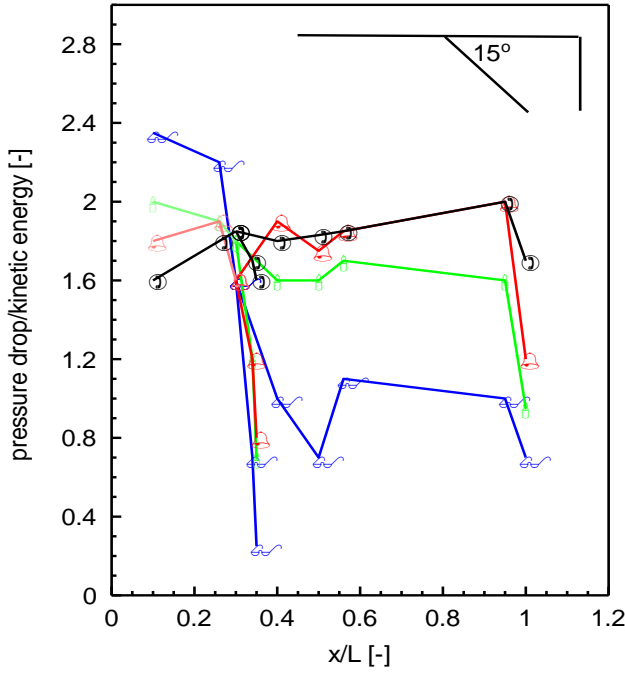

(b) Branched angle $=30^{\circ}$

$$
\text { -o - } \mathrm{A} / \mathrm{A}_{\mathrm{o}}=0.25,-\times-\mathrm{A} / \mathrm{A}_{\mathrm{o}}=0.50,-\Delta-\mathrm{A} / \mathrm{A}_{\mathrm{o}}=0.75 \text {, }
$$$$
-\square-\mathrm{A} / \mathrm{A}_{\mathrm{o}}=1.0
$$

Fig. 3 Pressure drop through main and branched duct at $\operatorname{Re}=10.2 \times 10^{4}$.

Figure 3 is devoted to $\operatorname{Re}=10.2 \times 10^{4}$ while Fig. 4 is devoted to $R e=4.6 \times 10^{4}$. Each figure consists of two parts (a) and (b) which are assigned for branched angles of $90^{\circ}$ and $30^{\circ}$ respectively. The study considers several cross-sectional areas for each branched angle. To study the effect of the cross-sectional area on the pressure drop, the same results are presented in Fig. 5. Each of the four parts of Fig. 5 represents the pressure drop related to the kinetic energy along different points. Parts (a, b, c and d) of Fig. 5 represent the results when $\mathrm{A} / \mathrm{Ao}=0.25, \quad 0.5, \quad 0.75$ and 1 respectively. Four curves are given in each part; which are

Case of $\operatorname{Re}=10.2 \times 10^{4}$ and Branched angle $=90^{\circ}$. Case of $R e=10.2 \times 10^{4}$ and Branched angle $=15^{\circ}$. Case of $\operatorname{Re}=4.6 \times 10^{4}$ and Branched angle $=90^{\circ}$. Case of $\mathrm{Re}=4.6 \times 10^{4}$ and Branched angle $=15^{\circ}$.

Since the study involves the investigation of many parameters on the pressure drop; it may be reasonable at this point; to represent the entire set of results in surface and contour formats. 

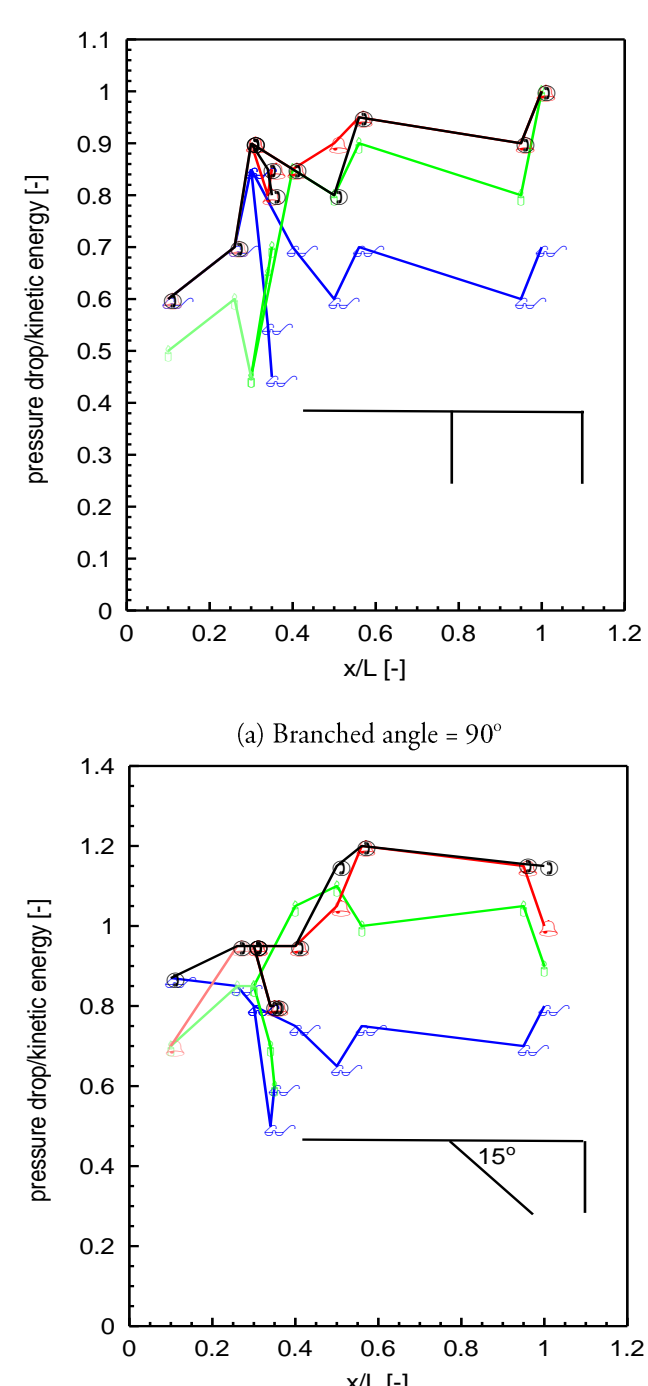

(b) branched angle $=30^{\circ}$

$$
-0-\mathrm{A} / \mathrm{A}_{\mathrm{o}}=0.25,-x-\mathrm{A} / \mathrm{A}_{\mathrm{o}}=0.50,-\Delta-\mathrm{A} / \mathrm{A}_{\mathrm{o}}=0.75 \text {, }
$$$$
-\square-\mathrm{A} / \mathrm{A}_{\mathrm{o}}=1.0
$$

Fig. 4 Pressure drop through main and branched duct at $\mathrm{Re}=$ $4.6 \times 10^{4}$

To study the effect of the area percentage and the $\mathrm{X} / \mathrm{L}$ ratio simultaneously; a three dimensional surfaces are given in Fig. 6. A set of subfigures are given in Fig. 7. The abscissa, in each of these subfigures, illustrates the $\mathrm{X} / \mathrm{L}$, while the ordinates are the pressure drop ratio. The four cases given in Fig. 7 represent the combination of $\operatorname{Re}$ of $\left(1.2 \times 10^{4}\right)$ and $\left(4 . \times 10^{4}\right)$ and a branching angle of $\left(15^{\circ}\right.$ and $\left.90^{\circ}\right)$.

It can be observed from Figs. 3, 5,6 and 7 that, at high Reynolds number, and at the entrance of the elbow, the pressure is rapidly decreased at full opening of the air exit and at $90^{\circ}$ with the axis of the main duct. Moreover, the pressure reached its minimum value at the branched part (3) for the same flow rate. This decrease may be associated with the increased eddy losses in the separated region due to the origin of turbulence. Therefore, the orientation of the outlet as well as the value of exit opening play an important role on the system characteristics as it is clear from (Figs.) $3,4,5,6$ and 7 where the angle of inclination was $15^{\circ}$. The pressure reached its minimum value at 0.75 exit opening with this ratio. At 0.25 exits opening the back pressure has a significant influence on the behavior of the flow as it is evidently observed on the left side of the loop. In case of $30^{\circ}, 45^{\circ}$, and $60^{\circ}$, no significant difference was noticed and for this reason the plot of the pressure drop has not been presented. These observations are supported by the previous studies down by Nisimura et al. [10]. In the experiments carried out by Nisimura et al. [10], the flow separation occurred slightly downstream, forming a recirculation vortex and then the separated flow region or the vortex expands rapidly. The fluid near the wall has anticipated the flow reverse and the fluid moves between the vortex and the wall at Reynolds number of $1.0 \times 10^{4}$. When the main flow reverses, the fluid passes between two vortices, forming high convoluted path.

For low Reynolds number Figs. 4, 5,6 and 7 the pressure within the inclined branch behaves in the same manner as that at higher Reynolds number but only for the full exit opening for both $15^{\circ}$ and $90^{\circ}$ angles on inclination. This can be attributed to the existence of secondary flow and eddies generated at high flow rates. For low flow rates, the back pressure is dominant as it is shown in both figures, where the loss of energy due to pressure drop increases. 
It can be concluded that the force on the branched stream is balanced with the pressure normal to the streamlines. In these cases the pressure increased in the stream wise direction as is clearly shown on the plots of branched regions. At the rest of the duct, the pressure difference behaviors are changed to be favorable as that expected in duct systems. It should be mentioned that the rate between the equivalent hydraulic diameter and the length of the test duct at the exit was 0.068 and 0.4 related to the total length and branched length of the duct respectively.

Based on the above results, it was observed that more narrowing of the air exit, put strong influence of the back pressure on the duct characteristics. These observations make it possible to rely upon using the present arrangement in air variable control system, where one of the main tasks is the reduction of energy losses due to pressure loop.

The present duct system can also be used to study the influence of non - isothermal air streams, passing through the branched exits, on the energy losses due to pressure drop and this could be considered in further studied.

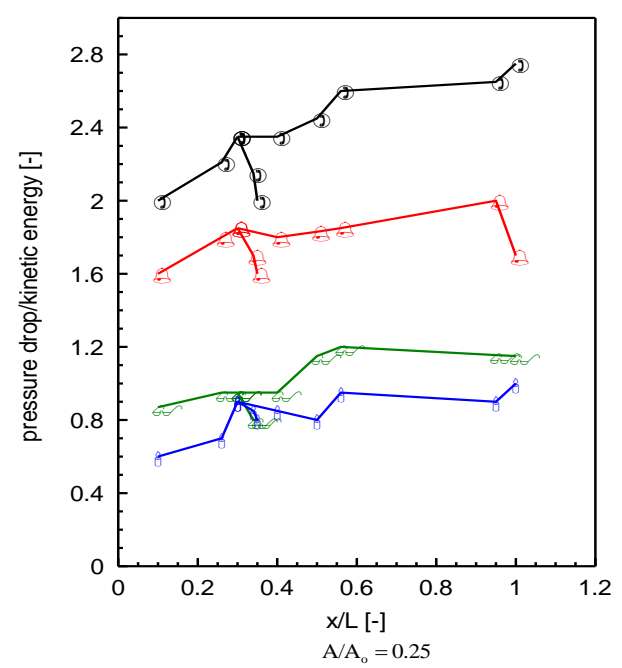

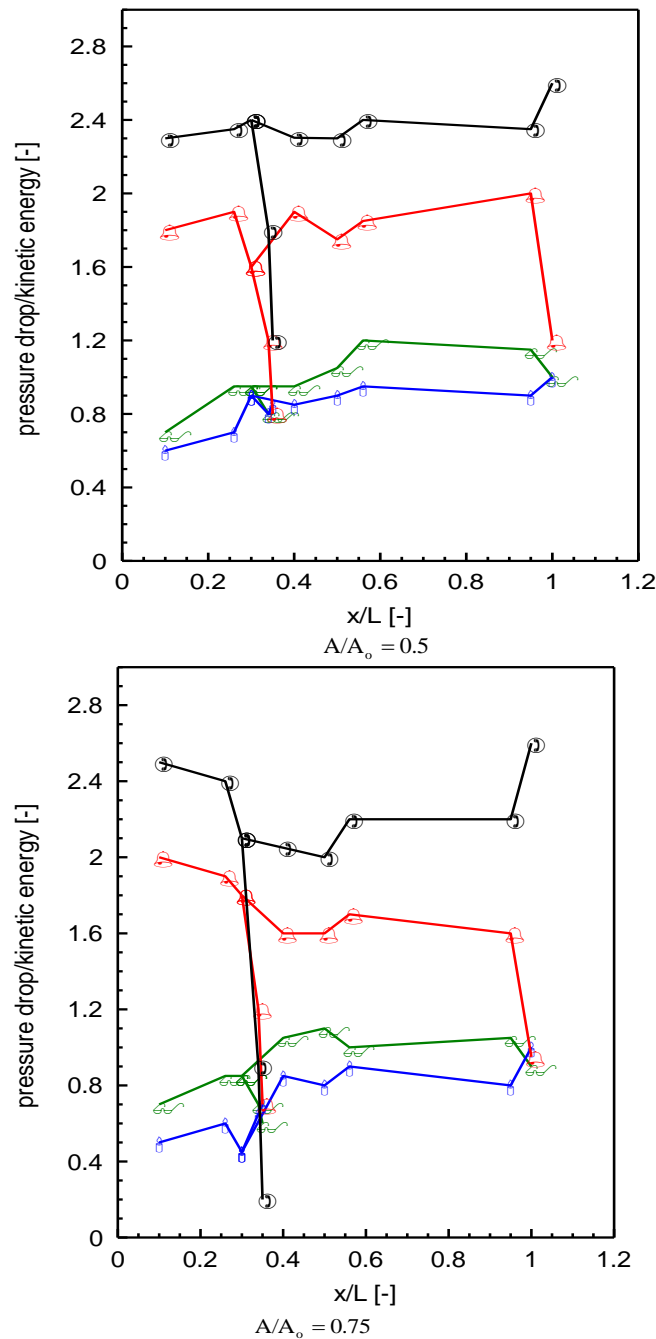

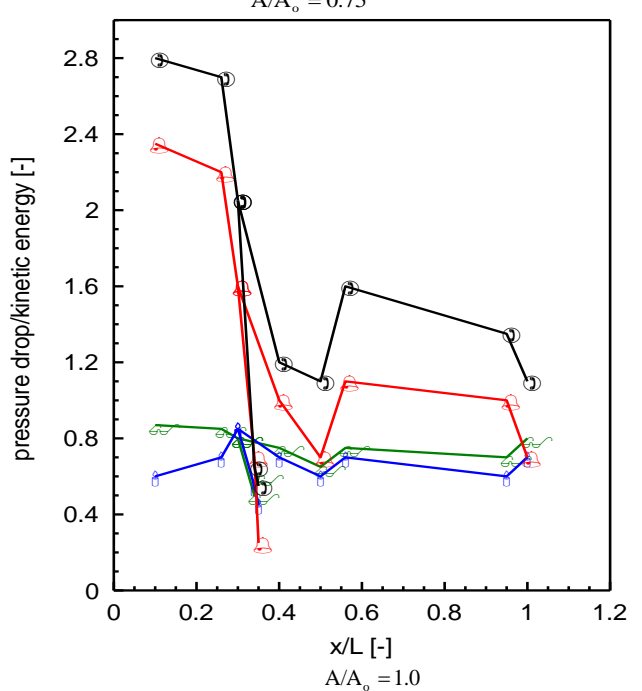

$-0-\operatorname{Re}=10.2 \times 10^{4}$, angle $=90^{\circ}$,

$-X-\operatorname{Re}=10.2 \times 10^{4}$, angle $=15^{\circ}$,

$-\Delta-\operatorname{Re}=4 . .6 \times 10^{4}$, angle $=90^{\circ}$,

$-\square-\operatorname{Re}=4 . .6 \times 10^{4}$, angle $=15^{\circ}$.

Fig. 5 Pressure drop through main and branched duct at different ratios $\mathrm{A} / \mathrm{A}_{0}$ 


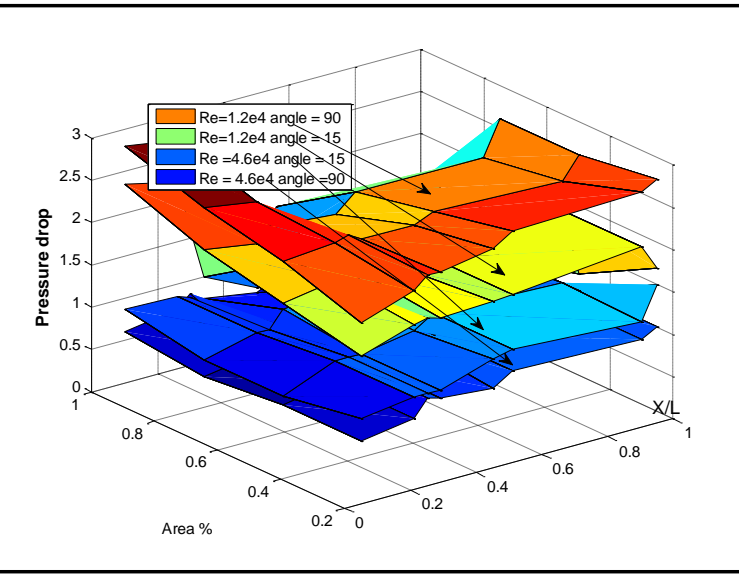

Fig. 6 Pressure drop surfaces
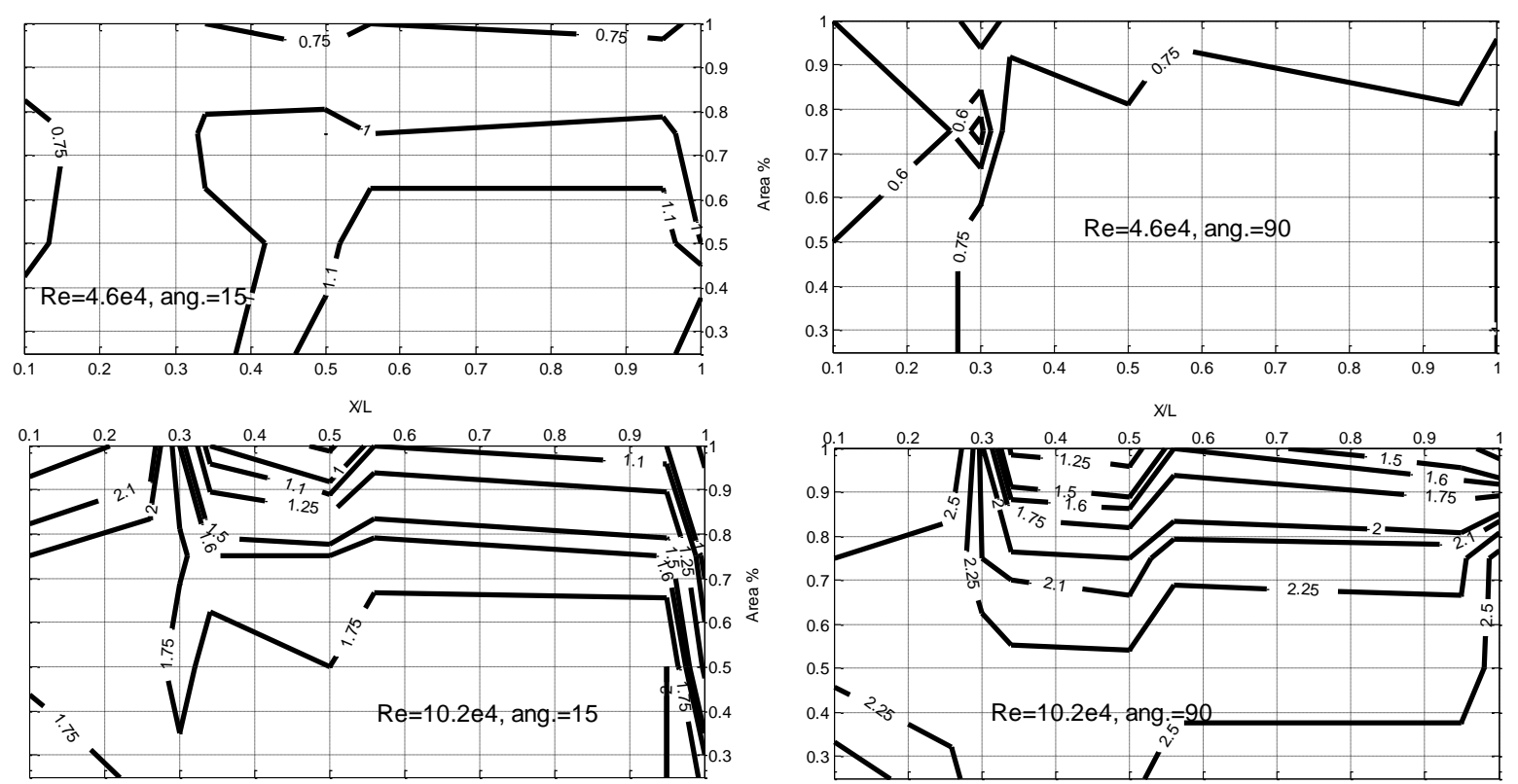

Fig. 7 Pressure drop contours

\section{CONCLUSION}

From the experimental investigation carried out, the following conclusions may be drawn:

1. The inclination of the branched duct has significant influence on the flow characteristics within the main duct.

2. The present duct arrangement could be successfully utilized in variable air volume control system.

3. With an angle of $90^{\circ}$, full exit opening with an angle of $15^{\circ}, 0.75$ opening, the pressure drop reached its minimum value in the inclined branch at exit.

4. More narrowing of air exit resulted in higher back pressure generation inside the duct at different sections.

\section{ACKNOWLEDGEMENT}

The authors wish to express their deep thanks and appreciation to the dr. k. M. A. kassem, and Dr. Fayez A. Mousa for their assistance to this work. 


\section{REFERENCES}

[1] McNown, J. S., "Mechanical of Manifold flow", Trans. ASCE, Vol. 119, 1954, pp. 1103-1142.

[2] Russ, E., "Head losses in way and Manifolds", Journal of the Hydraulic Division. ASCE, Vol. 3, 1970, pp 593-608.

[3] Kuho, T., and Ueda, T., "On the characteristics in divided flow and confluent flow in headers", Bulletin of JSME, vo1. 52, 1969, pp 802-809.

[4] Kuho, T., and Ueda, T., "On the characteristics of confluent flow of gas - liquid mixtures in headers", Bulletin of JSME, Vo1. 16 (99), 1973, pp 1376-1384.

[5] KOH, R.C.Y., and Brooks, N. H., "Fluid Mechanics of Waste Water Disposal in the Ocean", Annual Reviews of fluid Mechanics, Vol. 7, 1975, pp 187-1211.

[6] Acrivos, A., Babcock, B. D., and Plgford, R. H., "Flow distribuyion in manifolds", Chem. Eng. Sci., Vo1.10, 1959, pp 112-124.

[7] Dittrich, R., T., "Experimental study of Flow distribution and outlet manifolds", NACA Technical Note TN D 6697, 1972.

[8] Bajura, R. A., "A model for flow distribution in Manifolds", Journal of Enging. For power. Trans. ASME, 1971, Vo1.93, pp 7-12.

[9] Bajura, R. A., and Jones, J.r., E. H., "Flow distribution in Manifolds", Trans. ASME, Journal of Fluids Engineering, Vo1.98, 1976, pp 654-666.

[10] Nishimura, T., Tarumoto, A, and Kawamura, Y., "Mass transfer in enhancement in oscillatory flow in wavy channels", World Congress III of Chem., Tokyo, 1986, pp 483-486.

[11] Joon H. K., Hai K. S., Choong G. L., Young S. Y., Hee Ch. L., "Pressure and flow distribution in internal gas manifolds of a fuel-cell stack", Journal of Power Sources, Vol. 115, 2003, pp 5465.

[12] Chung H. Ch., Shiauh P. J., Shi-Chern Y. "Flow distribution in the manifold of PEM fuel cell stack", Journal of Power Sources, Vol. 173, 2007, pp. 249-263.

[13] Chung H. Ch., Shiauh P. J., Shi-Chern Y. "Analytical and experimental investigation of flow distribution in manifolds for heat exchangers", Journal of Hydrodynamics, Vol. 20, 2008, pp 179-185.
[14] Muzychka, Y. S., Yovanovichb, M. M., " Pressure Drop in Laminar Developing Flow in Noncircular Ducts: A Scaling and Modeling Approach", Journal of Fluids Engineering, ASME, vol. 131, 2009, pp 134-153.

[15] Brent Stephens1, Atila Novoselac and Jeffrey A. Siegel., "Impacts of HVAC Filtration on AirConditioner Energy Consumption in Residences", Proceedings of Healthy Buildings, ASME, 2009, pp 474-477.

\section{NOTATION}

$\begin{array}{ll}\text { A } & \text { Area }\left[m^{2}\right] \\ \mathrm{A}_{\circ} & \text { Full exit opening area }\left[m^{2}\right] \\ \mathrm{L} & \text { Total length of the main duct }[\mathrm{m}] \\ \Delta \mathrm{P} & \text { Pressure drop }[\mathrm{Pa}] \\ \mathrm{R}_{\mathrm{e}} & \text { Reynolds number }[-] \\ \mathrm{V} & \text { Velocity }[\mathrm{m} / \mathrm{s}] \\ \mathrm{X} & \text { Axial length }[\mathrm{m}] \\ \mathrm{P} & \text { Density }\left[\mathrm{kg} / \mathrm{m}^{3}\right]\end{array}$




\title{
بحث تجريبي على هبوطِ الضغطِ خلال القتواتِ المُتَقَرَّعِة
}

\author{
بهجت خميس مرسى ، فهذ المفضي، عبد الرحيم عماد \\ قسم الهندسة الميكانيكية - كلية الهندسة - جامعة القصيم - المملكة العربية السعودية
}

الملخص:

تم تصميم وإنشاء جهاز البحث التجريبي- المستخدم في هذا البحث- ليكون مشابهاً ل نظامَ أنبوب هوائي يستعملَ في العملياتِ الصناعيةِ ومسارات التكيفِ. يتكون الجهاز من فرع رئيسي وآخر مائلا عليه. المسار الثاني (المائل) صمم بحيث يمكن تغيير زاويةِ ميله من150 إلى $90^{\circ}$ على المحور الرئيسي وتم قياس مفاقيد الطاقِة في هبوط الضَنْطَ خلال مسار الهواء في نقاط مختلفة عند قيم متغيرة لرقم رينولدز من 104 4.6 إلى 10.2× 10.2. هدف هذا البحث قياس وبالتالي توقع مفاقيد الضغطَ خلال نظامِ دفع الهواء في المسارات الرئيسية والفرعية عند تغير زاوية ميل المسارات الفرعية ومساحة مقطعها مع ظروف تشغيل مختلفة لرقم رينولدز . كذلك يهدف البحث لتحديد قيمة الحد الأدنى للهجوط في الضغطِ . ولقد أوضحت التجارب أن هذه العوامل لها تأثثر هامّ على مفاقيد الطاقة.

النتائج المستخلصة من البحث أثنتت أن مفاقيد طاقة الضغط تصل إلى الحد الأدنى عندما نكون نسب مساحة المقطع الفرعي إلى مساحة المقطع الرئيسي تساوى 1.0 أو 0.75 وزاوية ميل المسار الفرعي تساوي $90^{\circ}$ أو $15^{\circ}$ ويمكن تعليل ذلك لهجودِ التدفقِ الثانويٍ وأيضاً الضغطِ الخلفِ داخل المسارات. هذه الملاحظةِ الهامِةِ نَجْعلُ من الممكن الاستفادة من البحث عند تصميمٍ نظامِ دفع الهواء داخل المسارات في التطبيقات الصناعية المختلفة عطياً. 